Review

\title{
Tissue Engineered Transcatheter Pulmonary Valved Stent Implantation: Current State and Future Prospect
}

\author{
Xiling Zhang ${ }^{1,2,+}$, Thomas Puehler ${ }^{1,2,+} \mathbb{D}$, Jette Seiler ${ }^{1,2}$, Stanislav N. Gorb ${ }^{3} \mathbb{D}$, Janarthanan Sathananthan ${ }^{4}$, \\ Stephanie Sellers ${ }^{4}$, Assad Haneya ${ }^{1}$, Jan-Hinnerk Hansen ${ }^{5}$, Anselm Uebing ${ }^{2,5}$, Oliver J. Müller ${ }^{2,6} \mathbb{D}_{\text {, }}$ \\ Derk Frank ${ }^{2,6}$ and Georg Lutter $1,2, *$ D
}

\section{check for}

updates

Citation: Zhang, X.; Puehler, T.;

Seiler, J.; Gorb, S.N.; Sathananthan, J.; Sellers, S.; Haneya, A.; Hansen, J.-H.; Uebing, A.; Müller, O.J.; et al. Tissue Engineered Transcatheter Pulmonary Valved Stent Implantation: Current State and Future Prospect. Int. J. Mol. Sci. 2022, 23, 723. https://doi.org/ $10.3390 /$ ijms 23020723

Academic Editors: Barbara Zavan, Stefano Sivolella and Alfredo Ronca

Received: 17 December 2021

Accepted: 5 January 2022

Published: 10 January 2022

Publisher's Note: MDPI stays neutral with regard to jurisdictional claims in published maps and institutional affiliations.

Copyright: (C) 2022 by the authors. Licensee MDPI, Basel, Switzerland. This article is an open access article distributed under the terms and conditions of the Creative Commons Attribution (CC BY) license (https:// creativecommons.org/licenses/by/ $4.0 /)$.
1 Department of Cardiovascular Surgery, University Hospital Schleswig-Holstein (UKSH), D-24105 Kiel, Germany; zhang_xiling@outlook.com (Z.X.); thomas.puehler@uksh.de (T.P.); jette.seiler@uksh.de (J.S.); assad.haneya@uksh.de (A.H.)

2 DZHK (German Centre for Cardiovascular Research), Partner Site Hamburg/Kiel/Lübeck, D-20251 Hamburg, Germany; anselm.uebing@uksh.de (A.U.); oliver.mueller@uksh.de (O.J.M.); derk.frank@uksh.de (D.F.)

3 Department of Functional Morphology and Biomechanics, Zoological Institute, Christian-Albrecht University of Kiel, D-24105 Kiel, Germany; sgorb@zoologie.uni-kiel.de

4 Department of Centre for Heart Valve Innovation, St Paul's Hospital, University of British Columbia Vancouver, BC V5K 0A1, Canada; jsathananthan@providencehealth.bc.ca (J.S.); SSellers@providencehealth.bc.ca (S.S.)

5 Department of Congenital Heart Disease and Pediatric Cardiology, University Hospital Schleswig-Holstein, Campus Kiel, D-24105 Kiel, Germany; JanHinnerk.Hansen@uksh.de

6 Department of Cardiology and Angiology, University Hospital Schleswig-Holstein (UKSH), D-24105 Kiel, Germany

* Correspondence: georg.lutter@uksh.de

$\dagger \quad$ These authors contributed equally to this work.

\begin{abstract}
Patients with the complex congenital heart disease (CHD) are usually associated with right ventricular outflow tract dysfunction and typically require multiple surgical interventions during their lives to relieve the right ventricular outflow tract abnormality. Transcatheter pulmonary valve replacement was used as a non-surgical, less invasive alternative treatment for right ventricular outflow tract dysfunction and has been rapidly developing over the past years. Despite the current favorable results of transcatheter pulmonary valve replacement, many patients eligible for pulmonary valve replacement are still not candidates for transcatheter pulmonary valve replacement. Therefore, one of the significant future challenges is to expand transcatheter pulmonary valve replacement to a broader patient population. This review describes the limitations and problems of existing techniques and focuses on decellularized tissue engineering for pulmonary valve stenting.
\end{abstract}

Keywords: tissue engineering; heart valve replacement; pulmonary; transcatheter; percutaneous; biodegradable; nitinol; stents; congenital heart disease; decellularization; recellularization

\section{Introduction}

The incidence of congenital heart disease (CHD) is approximately $9 \%$ in newborns [1]. Approximately $20 \%$ of newborns with CHD have malformations of the pulmonary valve or right ventricular outflow tract (RVOT), such as tetralogy of Fallot, one common arterial trunk, or pulmonary atresia [2]. In this patient group, surgical correction in the first month of life improves patient prognosis [3]. Surgical strategies for RVOT reconstruction include transannular patch enlargement, bioprosthetic valve placement, and valved conduits [4]. The tolerability of surgical intervention of the RVOT for complex CHD depends on the patient's age and the type of tissue material used [4,5].

However, multiple complications such as pulmonary regurgitation, self-growth, external ductal stenosis, valvular stenosis, ductal distortion, sternal compression, intimal 
hyperplasia, external ductal calcification, and deformation of the aneurysm lead to progressive RVOT dysfunction in these patients $[4,6]$.

Therefore, repeated surgical interventions are required throughout their lives. Despite the low mortality rate of surgical interventions, complications are significantly higher, especially in patients undergoing repeated procedures $[7,8]$.

In this clinical context, transcatheter pulmonary valve replacement (TPVR) has emerged as a non-surgical, less invasive alternative treatment for RVOT dysfunction.

In 2000, Bonhoeffer et al. [9] successfully performed the first TPVR using a bare-metal platinum alloy stent and a manually sewn flap bovine jugular vein $[2,10]$. In the decade since then, catheter-based valve implantation has evolved rapidly. As a result of TPVR, the interval between surgical replacements has approximately doubled [11]. Although the results are encouraging, the heterogeneity of this patient population and the diversity of morphology, size, and hemodynamics of the implantation site allow for TPVR in only about $15 \%$ of patients, which means that surgical pulmonary valve replacement is still necessary for $85 \%$ of patients, limiting the applicability of TPVR [12].

In addition, valve implantation is not without complications. The prosthetic valves currently used in clinical practice have significant deficits. Mechanical valve replacements require lifelong anticoagulation therapy, with the attendant risk of bleeding and thromboembolism [13], while biological valves are poorly durable, with an average useful life of only about 7 to a maximum of 15 years, due to changes such as calcification and decay in the distant future $[14,15]$. Moreover, since the allograft or homograft may never grow, it was a pitfall for younger patients, meaning they may have to undergo multiple surgeries [16]. Despite the use of transcatheter valves, interventions were required every 2.6 years (median) [11].

Tissue engineering is a multidisciplinary field that aims to develop biological tissues that can be used in the clinical treatment of diseases. Tissue-engineered products have proven to be effective in different applications, such as burn treatment or drug screening. The success of this approach in other medical fields has established the foundation for its application in heart valves [17-22]. A new alternative therapy to replace faulty valve grafts is emerging-tissue-engineered heart valves. These limitations are being overcome by tissue-engineered heart valves that are living, non-cytotoxic, and mechanically analogous heart valve replacements, and can grow and remodel with the patient. However, living valves still have insurmountable problems, including the choice of living material, the complexity of in vitro culture, and how the valves are stored. All of these issues have hindered the commercialization of tissue-engineered heart valve therapies.

This review discusses the applications and limitations of TPVR and the practice and prospects of tissue-engineered valved stents.

\section{Transcatheter Pulmonary Valve Replacement in Large Right Ventricular Outflow Tracts}

TPVR currently has a high success rate with favorable safety and prognosis. A $96.2 \%$ success rate was reported in a previous meta-analysis [23]. Data from US clinical trial data, the freedom from 5-year reintervention and reinsertion rates were reported to be were $76 \pm 4 \%$ and $92 \pm 3 \%$, respectively [24]. However, the current indications for TPVR are limited to postsurgical RVOT dysfunction with an enlarged ductal internal diameter between 16-24 mm (Melody valve, Figure 1A) and 21-27 mm (SAPIEN valve, Figure $1 \mathrm{~B})[16,25,26]$. It is estimated that only $15 \%$ of patients with CHD and RVOT dysfunction meet such stringent criteria $[12,27]$. Most patients who would benefit from TPVR are those with non-indicated applications, such as native RVOT or RVOT enlarged by transannular patch, bioprosthetic valves, or small internal diameter $(<16 \mathrm{~mm})$ of external ducts. 
A

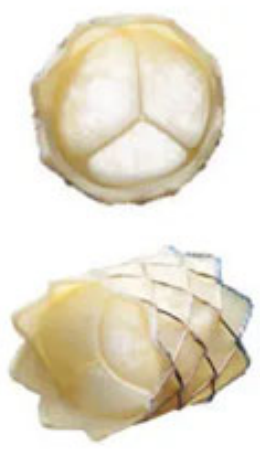

C
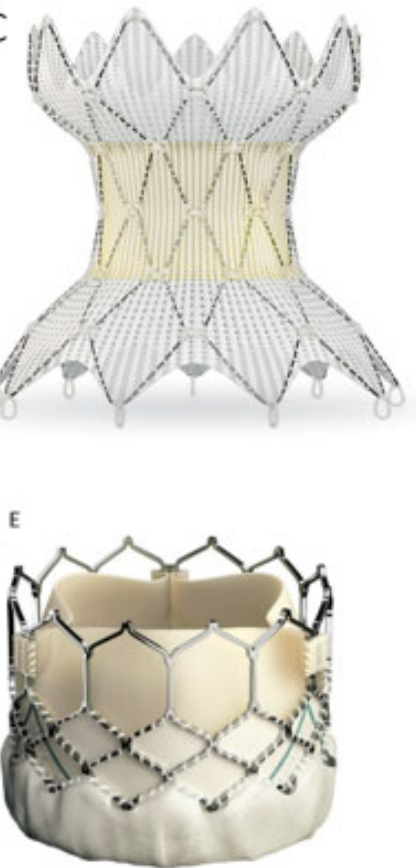

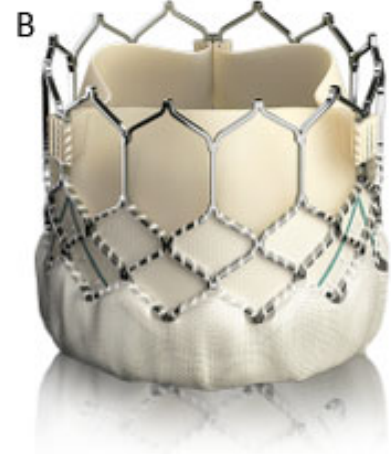

D

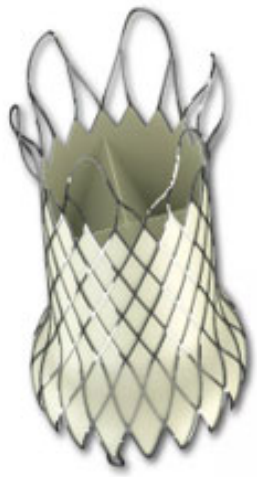

Figure 1. (A) Medtronic Melody Pulmonary valve, comprised of a bovine jugular vein valve sutured within a platinum iridium frame; with the permission of reproduction by Medtronic Inc. (B) Edwards SAPIEN 3 valve, made of bovine pericardial tissue attached to a balloon-expandable, cobalt-chromium frame for support; with the permission of reproduction by Edwards Lifesciences Inc. (C) Medtronic HARMONY Transcatheter Pulmonary Valve, comprised of porcine pericardial tissue valve and self-expanding nitinol frame with polyester cloth covering; with the permission of reproduction by Medtronic Inc. (D) VenusP-Valve, consisting of a self-expanding stent made of nitinol with a tri-leaflet porcine pericardial tissue; with the permission of reproduction by Venus Medtech Inc. (E) Edwards SAPIEN XT valve, made of bovine pericardial tissue with high radial strength cobalt-chromium frame with low frame height design; with the permission of reproduction by Edwards Lifesciences Inc.

Boshoff et al. [27] reported 23 cases of TPVR applied non-indicatively, including 8 cases of enlarged RVOTs with transannular patches without external conduits, 2 cases of pulmonary valve stenosis, and 13 cases of external conduits with small internal diameters. At a mean follow-up time of 1.2 years, the peak RVOT pressure difference was significantly lower, and no more than mild pulmonary regurgitation was present. Two patients were reintervened for the development of restenosis. No vascular complications, stent disruption, or valve migration occurred during follow-up. Meadow et al. [28] found a solution to the right ventricle-to-pulmonary artery pressure difference, successfully following 31 patients with TPVR for RVOT dysfunction on their own or without an external conduit. Similar encouraging results were observed in cases of percutaneous "valve in valve" after biologic valve dysfunction. A total of 104 cases of TPVR after biologic valve dysfunction were 
reported by Gillespie et al. [29] At a median follow-up of 1 year, four cases of restenosis with no more than mild pulmonary regurgitation were observed, and at follow-up, stent disruption was observed in two cases, none of which required further intervention. Overall, the 2-year reintervention-free rate was $>90 \%$, and no operation-related deaths occurred.

There are clearly increased complications associated with non-indicated applications compared to strict adherence to indications as well as issues related to liability and ethics for non-indication applications. However, situations exist in which TPVR is clinically indicated in healthcare settings based on published data or standard practice, but it remains non-indicated if applied by regulatory agency regulations. In such cases, patients may be deprived of effective therapeutic measures because of strictly limited indications. As TPVR technology evolves, more and more large clinical studies on the use of TPVR in small inner diameter, non-tubularly placed RVOT cases will be conducted, expanding the indications for TPVR in the near future.

A range of innovative techniques are emerging to expand the population for TPVR, particularly in patients with dilated RVOTs.

In 2010, Schievano et al. [30] reported a case of successful transcatheter self-expanding pulmonary valve expansion (Figure 2). This device was later called the Native Outflow Tract device (Medtronic, Figure 1C). It has an hourglass contour line with relatively large internal diameters at the ends and relatively small internal diameters in the middle. The self-expanding properties of the nitinol stent could, in theory, improve valve stability in the presence of different RVOT morphologies. At 6-month follow-up, no stent fracture and only trivial paravalvular leakages were observed.
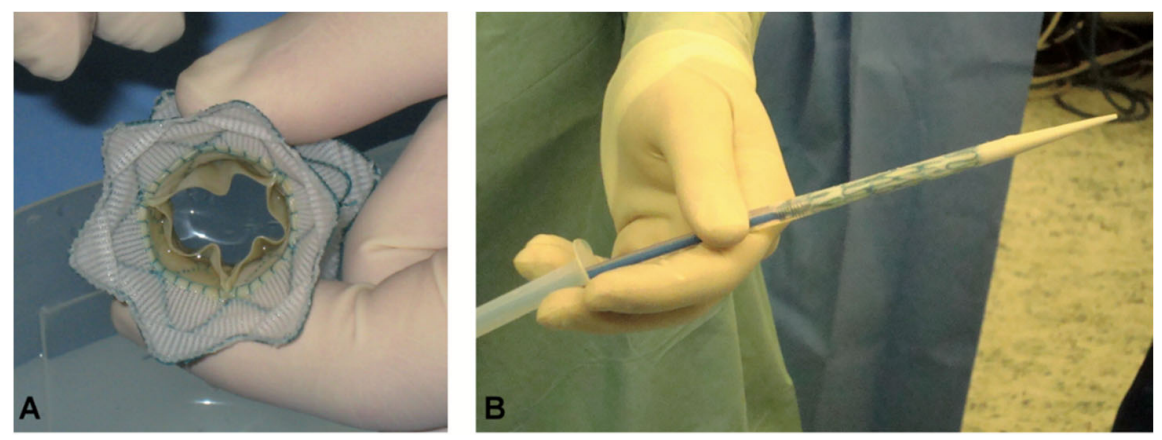

Figure 2. New device: (A) An end-on-view of the new device showing the Nitinol stent with graft covering and the open pericardial valve leaflets. (B) The delivery system with the device crimped and loaded onto the distal end (right side of picture) [30].

The Venous P valve stent (Shanghai, China,Figure 1D) is also a novel self-expanding percutaneous pulmonary device consisting of a three-lobed porcine pulmonary valve and a surrounding nickel-titanium metal stent frame delivered by a 14- or 22-F sheath, with valve sizes ranging from 20 to $32 \mathrm{~mm}$. Small clinical studies have confirmed the safety and efficacy of the Venous pulmonary valve stent [31,32]. Given the ability of this device to fit the enlarged RVOT via a transannular patch, this device will play an important role in widening the indications for TPVR in the future if additional clinical studies confirm these positive results.

Similarly, the Sapien XT (Edwards, Figure 1E) $29 \mathrm{~mm}$ size valve can be used as an alternative treatment for larger inner diameter RVOTs; although, this valve has not been explicitly studied in the pulmonary artery position. A percutaneous pulmonary valved stent designed to reduce the internal diameter of the RVOT has been successfully placed in the RVOT of sheep, but it is still in preclinical trials [33,34]. Other advanced techniques have been successfully used in patients with disseminated, complex RVOT geometry, including placement of Melody transcatheter pulmonary valves in both pulmonary arteries [35], and the pulmonary artery "jailing" technique in which a folded bare metal stent is bifurcated from the pulmonary artery into the RVOT to distend it as an anchor for TPVR [36]. 
However, there are still some problems to overcome, such as tricuspid valve injury, paravalvular leakages, stent migration, arrhythmia, stent fracture, etc. [37]. The stent grafts for patients with large native or patched RVOT diameters $(>30 \mathrm{~mm})$ cannot be addressed solely by the transcatheter aortic valve stents currently available on the market. An innovative transcatheter stent must be developed to remove surgical limitations.

\subsection{Development of Tissue-Engineered Pulmonary Valves}

While pulmonary valve replacement can be lifesaving in pediatric and adolescent patients, there is a critical problem: the graft cannot grow. This means that such patients may have to undergo multiple surgeries, increasing the risk of complications and even death. To address this problem, tissue-engineered valves can create a living heart valve with excellent self-repair and reconstruction capabilities that can overcome the various disadvantages of current prostheses. Tissue engineering can enhance the ability of damaged, malformed, or diseased valve tissue to heal itself by guiding the reconstruction of a native extracellular matrix (ECM) bionic microenvironment with appropriate biomechanical properties, as well as providing the necessary bionic physical and biological stimuli. Synthetic resorbable valves with bionic function not only transport cells but also provide mechanical support and bio-stimulation to promote valve regeneration, thus meeting a variety of clinical needs [38]. The construction of novel valve materials by means of tissue engineering is expected to overcome the shortcomings of current valve materials. The tissue-engineered heart valve (TEHV) is constructed by using a combination of porous cell scaffolds, seed cells, and bioactive factors with the ultimate goals of: (1) providing excellent hemodynamics without anticoagulation therapy, (2) promoting tissue remodeling and preventing valve degradation, and (3) having regenerative characteristics to avoid reoperation. TEHV cellular scaffolds mainly include natural material stents (such as decellularized tissue or biomaterials) versus synthetic material stents (degradable polymers).

\subsection{Decellularized Tissue-Engineered Heart Valve}

Decellularization is removing cells (including the nucleus) from the ECM of biological tissue. After cell removal, the remaining ECM provides a cellular scaffold with voids, which not only retains the complex geometry of natural tissues but also consists of natural components that promote cell migration and differentiation, resulting in constructive remodeling. In addition, decellularized valves do not require complete degradation and can maintain their own anisotropic mechanical properties. To date, decellularized heart valves (DHVs) are more favorable than synthetic-material valves for clinical applications, and implantation has been accomplished in animals and humans as valve replacements.

Although decellularized tissues have been used clinically for many years, it was not until 2011 that generally accepted quantifiable minimum criteria for moderate decellularization was generated [39]: in samples with (1) double-stranded DNA (dsDNA) content < $50 \mathrm{ng} / \mathrm{mg}$ ECM dry weight; (2) DNA fragment length < $200 \mathrm{bp}$; and (3) no visible nuclei in sections stained with 4',6-diamidino-2-phenylindole (DAPI) or hematoxylin-eosin (H\&E) stained tissue sections without visible nuclei.

These criteria list the essential indicators to be met for clinically applicable decellularized tissues because incomplete decellularization can affect the human immune response by affecting macrophage polarization and inhibiting constructive matrix remodeling. Although decellularization does preserve the natural tissue geometry, inappropriate decellularization methods can negatively affect the natural three-dimensional ultrastructure of the matrix, the surface topology, and the composition of matrix proteins.

\subsection{Seed Cells and Recellularization of Tissue-Engineered Valves}

The body's heart valves consist of mainly interstitial valve cells and endothelial cells. Endothelial cells cover the valve leaflet surface and serve as an essential protective barrier between the interstitial cells and the extracellular matrix, while endothelial cells also regulate the coagulation system. The current biological valves in clinical use are pericardial 
membranes prepared using glutaraldehyde cross-linking. The pericardium itself has no endothelial cells, and the endothelialization, of biologic valves can effectively delay or prevent the decay and calcification of biologic valves, which may fundamentally solve the problem of biologic valve durability, and effort is directed to develop new biologic valves with very important clinical significance [40].

There are two ways of achieving biological valve re-endothelialization [41]: in vitro and in vivo. For in vitro re-endothelialization, host endothelial cells are cultured in vitro and grown on the surface of the bioprosthetic valve. Dohmen et al. [42] isolated, cultured, expanded, and seeded human transcatheter endothelial cells on human post-decellularized pulmonary valves with good results after surgery. In vitro re-endocytosis faces many difficulties and challenges, including the source of seeded cells, efficiently achieving an expansion of seeded cells, and possible immune rejection. In vivo re-endothelialization, or in situ recellularization, refers to the implantation of decellularized biologic valve scaffold tissue directly into the body, where the host's own endothelial cells grow and crawl. Elkins et al. [43] implanted decellularized sheep pulmonary artery valves into young sheep for 6 months and found good valve recellularization. The mechanisms of in vivo endothelialization identified so far include: (1) crawling growth of endothelial cells from the injured portion; and (2) deposition of seed cells onto the endothelial surface using blood circulation, also known as sedimentation healing. In vivo reendothelialization/in situ recellularizations may be a more suitable strategy for clinical application than in vitro recellularization.

\subsection{Effects of Seed Cells on Recellularization}

The recellularization process is influenced by various factors such as the characteristics of the seed cells and the culture environment, the nature of the scaffold material itself, and the cell-scaffold material interaction. Seed cells can generally be divided into adult cells (primary cells) and stem cells (or precursor cells that differentiate in a specific direction).

Earlier, a variety of adult cells such as endothelial cells, VIC, and myofibroblasts were used for the study of DHVs recellularization. The use of autologous endothelial cells (of vascular or stem cell origin) grown in vitro in DHVs results in a better endothelial cell layer $(\mathrm{vWF}+)$ on the valve surface, which provides some protection to the valve tissue [44-47]. However, in the absence of mesenchymal cells, it is challenging to keep the formed endothelial cell layer stable in the presence of hemodynamic shock from physiological conditions. Other studies have attempted to implant mesenchymal type cells (cardiac mesenchymal cells) in DHVs, or endothelial and mesenchymal type cells (myofibroblasts) together [48-50], and have shown that some degree of endothelialization and infiltration of mesenchymal cells $(\alpha \mathrm{SMA}+, \mathrm{VIM}+)$ can be achieved; although, there is a disparity in cell volume and cell distribution with natural valves.

In recent years, with the increasing maturity of stem cell technology, many studies have started to use stem cells in attempts to recellularize DHVs. The potential for multidirectional differentiation and the ability of self-renewal of stem cells make them theoretically advantageous as seed cells, and the commonly used ones are mesenchymal stem cells (MSC), endothelial progenitor cells, embryonic stem cells, and induced multifunctional stem cells. MSCs are derived from bone marrow or adipose tissues and are most widely used today. They can transform to endothelial cell phenotypes in the presence of vascular endothelial growth factor (VEGF) and under conditions such as higher fluid shear [51,52], and also have mesenchymal cell phenotype transformation potential [53].

Vincentelli et al. [54] injected receptor-derived MSCs into the mesenchyme of porcine DHVs and then implanted them into sheep pulmonary valve sites, which resulted in the formation of an intact endothelial layer and a distribution of mesenchymal cells similar to that of natural pulmonary valves after 4 months. Endothelial progenitor cells are mainly obtained from peripheral blood or umbilical cord blood and differentiate mainly to endothelial cells during maturation, but can also exhibit a mesenchymal cell phenotype under certain conditions [55]. Embryonic stem cells are derived from embryonic tissues and induced multifunctional stem cells are derived from somatic cells. Both have high 
differentiation potential and can be induced to transition into endothelial or mesenchymal cell types by a suitable environment, providing favorable environmental conditions for the full recellularization of DHVs.

In the process of decellularization, the ECM is inevitably destroyed. Therefore, to improve the ability of seed cells to adhere, proliferate, migrate, and differentiate, bioactive factors such as cytokines, antibodies, and peptides can be applied to modify and promote endothelialization. The main growth factor commonly used is VEGF [56]. VEGF is associated with the recruitment of endothelial cells or endothelial progenitor cells in the bloodstream. VEGF-based surface modification strategies can improve the endothelialization of biological heart valves. Hopkins et al. [57] used bioengineered (decellularized with collagen conditioning treatments) human and baboon heart valve scaffolds implanted in baboons, and the treated valves were less immunogenic, had a less inflammatory response, and were well recellularized with good valve function. Jordan et al. [15] combined CD133+ cells isolated from peripheral blood with the surface of porcine DHVs and achieved complete endothelialization 1 month after implantation into sheep, and mesenchymal cells, matrix metalloproteinases, and collagen were significantly higher after 3 months than in both the DHVs group and the DHVs group implanted with autologous endothelial progenitor cells in vitro. Our group [58] also demonstrated that bone marrow-derived CD133+ cells on DHVs had better results concerning possible calcification, inflammation, and transvalvular gradients compared to autologous carotid artery cells on DHVs in vivo.

\subsection{Effects of Bioreactors on Recellularization}

Heart valves, open and close approximately 100,000 times per day with each heartbeat in an in vivo blood flow environment. Static conditions in culture in vitro are far removed from the physiological environment in vivo. Many studies have attempted to simulate the dynamic environment in vivo to achieve better recellularization. Bioreactors can simulate physiological conditions of pressure pulses and blood flow environment in vitro to preadapt valve tissue to the complex environmental changes in vivo before implantation and to provide more favorable conditions for seed cell proliferation and differentiation.

Simulating the in vivo blood flow environment under hydrodynamic stimulation conditions can improve the success rate of re-endothelialization of stent materials. Lichtenberg et al. [59] found that complete endothelialization of DHVs could be achieved by providing hydrodynamic stimulation through a bioreactor and stepping up the flow rate of the solution in the reactor to physiological conditions, whereas increasing the flow rate too rapidly to physiological conditions resulted in the destruction of endothelial cells implanted on the surface of the scaffold material, which may explain the shedding of implant cells when tissue-engineered valves formed under static in vitro culture enter the body and are exposed to the physiological mechanics [60]. They further re-endothelialized DHVs using young sheep autologous endothelial cells in a bioreactor, and after 3 months of implantation into young sheep pulmonary valve sites, the endothelial coverage of the valve was increased and thrombus formation on the valve surface was reduced [61]. A similar approach was used for the implantation of sheep aortic valves, which showed no significant dysfunction after 3 months, with intact endothelial coverage and no signs of inflammation, whereas the cryopreserved implanted valves showed significant signs of calcification and decay [62].

A dynamic culture environment that mimics physiological conditions may also increase infiltration of mesenchymal type cells and facilitate the preservation of valve cell function after implantation. Schenke-Layland et al. [63] incubated myo-fibroblasts with DHVs under static conditions for $2 \mathrm{~d}$, then transferred them to a bioreactor for $9 \mathrm{~d}$ or $16 \mathrm{~d}$ before implanting endothelial cells in a static environment, which resulted in a better recellularization of the valve compared with static culture alone, with better coverage of the endothelial layer and significant infiltration of mesenchymal cells.

Kajbafzadeh et al. [64] grew autologous MSCs in decellularized sheep aortic valves under pulsed conditions in a bioreactor, cultured them, and implanted them in the thoracic 
descending aortic position in sheep, eight recipients survived up to 19 months with no significant endothelial tears on CT at 18 months, and pathological sections showed that the valves reached a level of $\alpha \mathrm{SMA}+$ cellularity closer to that of natural valves. Cebotari et al. [65] grew single nucleated cells isolated from human peripheral blood in a bioreactor in decellularized human pulmonary valves. After $21 \mathrm{~d}$ of culture, endothelial cell-specific phenotypes were seen on the surface cells, which were then implanted in the pulmonary valve sites of two children with preexisting heart disease. During 3.5 years of follow-up, it was observed that the implanted pulmonary valves maintained relatively good function and showed growth without significant failure.

\subsection{In Vivo In Situ Recellularization Procedure}

In contrast to in vitro recellularization, many research teams have attempted to implant DHVs directly into the body, hoping that it will guide specific cell aggregation, adhesion, proliferation, and differentiation in vivo to achieve in situ recellularization, which is also called "guided tissue regeneration" [66]. Compared to in vitro recellularization, this method recruits and differentiates cells in vivo without the need for autologous cell isolation, implantation, and culture processes, and the in vitro treatment process is relatively simpler and shorter. Some studies have found that in vivo implantation in mice results in more complete in situ recellularization [67], but most implanted valves in pigs or sheep show only endothelial coverage or infiltration of inflammatory cells [66,68-74], suggesting that it may be more difficult to achieve complete recellularization directly in vivo in larger animals. Rabbit aortic valves implanted in dogs showed rapid failure [75], whereas porcine-DHVs implants in dogs or sheep developed better endothelialization [76,77], suggesting that small animal valves implanted in large animals may be less likely to achieve recellularization and less durable.

\subsection{Tissue-Engineered Pulmonary Valves in the Clinic}

To date, young patients including pediatric patients undergoing pulmonary valve replacement continue to face the dilemma that neither mechanical valves nor xenobiotic valves are ideal. Therefore, the homogeneous allogeneic pulmonary valve remains the best option currently: cryopreserved, homogeneous valves have good hemodynamic performance, low incidence of thromboembolism and infection, and better durability than other biologic replacements. A concomitant problem, however, is the degradation of homograft valves over time, which is particularly evident in children and young adults [16].

The results of animal trials with decellularized valves have been encouraging, with animals surviving up to 9 months after surgery, but their clinical trial results have been mixed: in clinical practice, the majority of decellularized valves used are xenografts rather than homografts due to the scarcity of human tissue, and clinical practice with xenograft decellularized valves has not been encouraging. The SynerGraft ${ }^{\circledR}$ valve from CryoLife, a decellularize valve of porcine origin, showed good initial results in adults, but has triggered a severe immune response in pediatric patients [78].

Another product, Matrix $\mathrm{P}^{\circledR}$ and Matrix $\mathrm{P}$ plus, required reoperation for valve failure in $52 \%$ of children after implantation, and the implanted valve leaflets showed significant thickening with fibrosis, and severe inflammation without significant re-endothelialization $[79,80]$. Overall, although advances in the decellularization process or better pre-implantation conditioning may improve outcomes, the clinical performance of decellularized allogeneic valves is not superior to that of standard cryopreserved homogeneous valves.

On the other hand, human homogeneous decellularized valves have been more successful in clinical practice. Haverich et al. [81] conducted a decade-long study of decellularized pulmonary homografts (DPHs) valved stents. The results showed that the mid-term results of DPHs for PVR confirm earlier results of reduced re-operation rates compared with cryopreserved pulmonary homografts (CHs) and bovine jugular vein (BJVs) conduits, and growth potential is one of the unique features of DHPs. 
Preliminary results from a recent European multicenter prospective trial show that DPH has an appreciable safety and efficacy profile with good hemodynamics over a period of up to 3 years [82]. Evidence from multiple centers also indicates that decellularized allografts are consistent with conventionally cryopreserved allografts in a comparison of early and mid-term outcomes. Moreover, the explantation and degeneration rates are lower than those of conventional cryopreserved allografts [83-85].

In addition, data show that the CryoValve ${ }^{\circledR}$ SG valve, a human allogeneic decellularized valve developed by CryoLife, did not require reoperation in $93 \%$ of patients at 10 years, and was free of valve dysfunction in $85 \%$ of patients at 5 years after implantation and $75 \%$ of patients at 10 years after implantation [86]. Compared with the gold standard frozen (cryopreserved) human-derived valve (homografts), the CryoValve ${ }^{\circledR}$ SG valve was less likely to develop valve dysfunction and less likely to require re-intervention. However, the mean follow-up was only 5 years in this study, and more extended observation is still needed [86]. Table 1 demonstrates the clinical application of decellulized homogeneous pulmonary valves.

The primary advantage of decellularized valves over the gold standard cryopreserved human-derived valves (homografts) is the reduced antigenicity. This is because endothelial cells that survive cryopreservation can still express HLA antigens intact and undergo immune reactions that cause valve failure [87]. However, to date, complete autologous recellularization has not been achieved in implanted DHVs. Autologous recellularization of decellularized valves is limited to the valve wall, whereas on the leaflet surface, only the recellularization of endothelial cells has been observed. Although this has been significantly superior to cryopreserved valves (because of the severe degradation and leukocyte infiltration throughout the valve after frozen valve implantation), the problem that recellularization of decellularized valves is limited to the valve wall still limits their clinical application because the valve leaflet is the main site of dysfunction after cryopreserved valve implantation.

Without the ability to reconstitute living cell communities within the leaflet mesenchyme that can repair and remodel the ECM, DHVs will suffer the same fate as cryopreserved valves, i.e., gradual valve degradation after implantation. In addition, DHVs require human or animal tissue to manufacture, which is in limited supply and requires cryopreservation, yet freeze-drying destroys the structure of the ECM in the valve and leads to inactivation of biomolecules.

In addition, we should consider the cytotoxicity of decellularized tissue-engineered valves. Detergents commonly used are sodium deoxycholate (SDC), sodium dodecyl sulfate (SDS), and ethylenediaminetetraacetic acid (EDTA). Even after rinsing, detergent residue will remain. After surface seeding, Rieder et al. found that SDS-decellularized xenomatrices had a toxic effect on endothelial and myofibroblast cells [46]. Nevertheless, residue concentration $(<50 \mathrm{mg} / \mathrm{L})$ in the wash solution has not affected the receptiveness of decellularized matrices to human endothelial cells. Therefore, detergent concentrations less than $50 \mathrm{mg} / \mathrm{L}$ in the washing solution may be used as an indicator for the production of non-toxic tissues. Alternatively, a combination of detergents at medium concentrations can achieve good decellularization and can also be rinsed off more easily [88]. Decellularized TEHV needs to have long-term storability. Long-term storage may result in increased decellularized residues due to degradation of the ECM. The goal of future research should be to find optimal decellularization protocols and storage strategies since decellularization protocols and storage strategies still differ. 
Table 1. Clinical application of decellulized homogeneous pulmonary valves.

\begin{tabular}{|c|c|c|c|}
\hline Trial (Year) & Type of Homograft & Mean Age (Years) & Main Findings \\
\hline ESPOIR (2019) [82] & fDPVH & $21.3 \pm 14.4$ & $\begin{array}{l}\text { Excellent performance with freedom from } \\
\text { explantation and reintervention. Better safety and } \\
\text { effectiveness than BJV and } \mathrm{CH} \text {. }\end{array}$ \\
\hline Bobylev et al. (2018) [89] & fDPVH & Range 2-38 & $\begin{array}{l}\text { Superior mid-term results in children and young } \\
\text { adults for PVR. fDPVH provides an alternative } \\
\text { therapy for young patients who require multiple } \\
\text { valve surgeries. }\end{array}$ \\
\hline $\begin{array}{l}\text { Sarikouch et al. } \\
\quad \text { (2015) [81] }\end{array}$ & fDPVH & $15.8 \pm 10.21$ & $\begin{array}{l}\text { One-hundred percent freedom from explantation } \\
\text { and endocarditis for fDPVH compared with } \mathrm{CH} \\
\text { and BJV at 10-year follow-up, associated with no } \\
\text { increased valvular gradient. }\end{array}$ \\
\hline Cebotari et al. (2011) [83] & fDPVH & $12.7 \pm 6.1$ & $\begin{array}{c}\text { fDPVH showed the lower mean transvalvular } \\
\text { gradient and no cusp thickening or aneurysmatic } \\
\text { dilatation. Plus, five-year freedom from } \\
\text { explantation was } 100 \% \text {. fDPVH also exhibited } \\
\text { adaptive growth. }\end{array}$ \\
\hline Cebotari et al. (2006) [65] & fDPVH & Age 11 and 13 & $\begin{array}{l}\text { fDPVH was feasible and safe with potential to } \\
\text { remodel and grow (increase in annulus diameter). } \\
\text { There was no sign of valve degeneration at } \\
\text { 3.5-year follow-up. }\end{array}$ \\
\hline Dohmen et al. (2011) [90] & cDPVH & $39.6 \pm 10.3$ & $\begin{array}{l}\text { Excellent hemodynamic performance for up to } \\
10 \text { years with no evidence of calcification. }\end{array}$ \\
\hline Brown et al. (2011) [91] & cDPVH & $28.6 \pm 16.0$ & $\begin{array}{l}\text { No patients required reoperation and valve } \\
\text { function did not deteriorate. Clinical and } \\
\text { hemodynamic performance was encouraging and } \\
\text { did not differ significantly from } \mathrm{CH}\end{array}$ \\
\hline Burch et al. (2010) [92] & cDPVH & $9.95 \pm 7.96$ & $\begin{array}{c}\text { There was no significant difference in the trend of } \\
\text { lower peak valve gradient and re-intervention } \\
\text { between cDVPH and } \mathrm{CH} \text {. }\end{array}$ \\
\hline Dohmen et al. (2007) [93] & cDPVH & $44.0 \pm 13.7$ & $\begin{array}{l}\text { cDVPH showed excellent hemodynamic } \\
\text { performance, and may prevent valve degeneration } \\
\text { and improve valve durability }\end{array}$ \\
\hline $\begin{array}{l}\text { Hawkins et al. } \\
\text { (2003) [94] }\end{array}$ & cDPVH & $8.5 \pm 7.9$ & $\begin{array}{c}\text { After } 1 \text { year, the hemodynamic function of cDPVH } \\
\text { was similar to that of } \mathrm{CH} \text {, but the levels of class I } \\
\text { and class II HLA antibodies were significantly } \\
\text { lower in cDPVH than in } \mathrm{CH} \text {. }\end{array}$ \\
\hline
\end{tabular}

BJV: bovine jugular vein; cDPVH: cryopreserved decellularized pulmonary valve homograft; $\mathrm{CH}$ : cryopreserved homograft; fDPVH: fresh decellularized pulmonary valve homograft.

Despite the many advantages of allograft valves, both decellularized and conventional cryopreserved allograft valves have associated problems. In addition to the scarcity of raw materials, calcification occurs. This also dramatically reduces its availability. Currently, two types of materials are being studied, biological-based materials and synthetic-based materials. Decellularized valves made from collagen, elastin, fibrin, sodium alginate, chitosan, and other biomaterials have advantages in cell adhesion, migration, proliferation, and differentiation. However, their mechanical properties are fragile. Many polymeric heart valves are already in use. In fact, pulmonary monocusp valve prostheses made of polytetrafluoroethylene have been used for more than 20 years for the surgical treatment of RVOT abnormalities due to calcification or abnormal function in young patients with good results [95]. However, these materials were found to degrade and thrombose at an early stage [96]. Lutter et al. [97] described a novel low-profile self-expanding nitinol stent carrying a dip-coated pulmonary heart valve prosthesis made of polycarbonate urethane 
(PCU) and demonstrated promising results in animal experiments (Figure 3). PCU has been shown to have good biocompatibility, durability, and resistance to thromboembolism. It is expected to be an alternative to allograft pulmonary valves. Seed cells were also successfully colonized on polymeric heart valves. Aleksieva et al. [98] successfully seeded saphenous vein-derived endothelial cells and fibroblasts on polyurethane scaffolds. CD133+ cells were also successfully colonized on PCU [58]. Combining synthetic scaffolds with biological scaffolds is also being explored; for example, chitosan-modified polycaprolactone porous scaffolds can improve fibroblast adhesion on TEHV [99]. The use of synthetic heart valves in clinical applications, however, has not yet been reported.
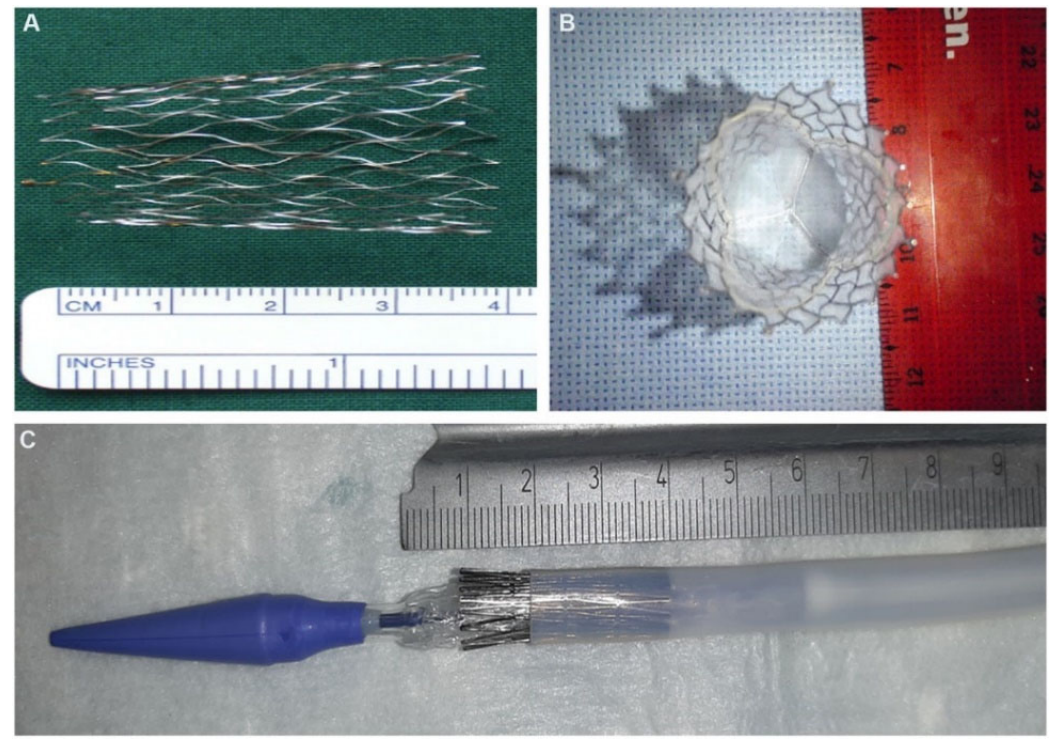

Figure 3. (A) Self-expanding nitinol stent, sizes $24 \mathrm{~mm}$ (ventricular) $/ 22 \mathrm{~mm}$ (middle)/20 mm (pulmonary) with an overall length of $35 \mathrm{~mm}$. (B) Top view of tricuspid polycarbonate urethane valved stent. (C) The valved stent is crimped in a 14-Fr delivery catheter with a smooth silicone structure at the proximal tip [97].

\section{Tissue-Engineered Transcatheter Pulmonary Valved Stent Implantation}

In patients with RVOT dysfunction, TPVR offers a minimally invasive treatment option that allows such patients to avoid repeat surgery. In contrast, the bovine jugular vein valve currently used in TPVR is a glutaraldehyde fixed heterogeneous valve that is prone to degeneration. Tissue-engineered valves offer a way to overcome the limitations of current heart valve replacements. Tissue-engineered valves are currently being used successfully in the clinic with good results. However, the current approach to tissue-engineered valve implantation still uses open-heart surgery rather than transcatheter minimally invasive surgery. There are still some tissue-engineered valve grafts in studies with stenosis and/or regurgitation, which are mainly caused by distal anastomotic stenosis [81]. Furthermore, valve regurgitation can occur when implantation is poor because decellularized grafts are soft. The growth potential is a unique feature of decellularized pulmonary valve grafts, but it depends on the recellularization of the graft. However, when the graft is in the setting of severe scarring, rapid and complete recellularization seems unlikely. Therefore, how to combine TPVR with tissue-engineered valves should be a focus of future research. While avoiding repeat surgery and overcoming the disadvantages of existing xenobiotic valves, Lutter's group $[100,101]$ successfully performed TPVR in a sheep model using an autologous tissue-engineered valve scaffold without regurgitation after 4 weeks, and angiography and echocardiography showed good opening and closing of the implanted heart valves. However, all animals developed arrhythmias (Figure 4). 


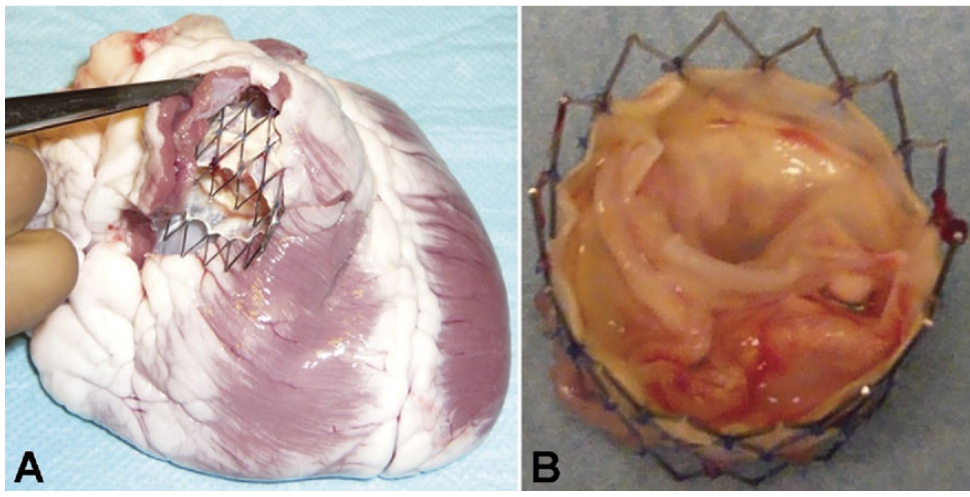

Figure 4. (A,B) Gross morphology of tissue-engineered pulmonary valved stent $[100,101]$.

There are several issues that still need to be addressed for transcatheter tissue-engineered pulmonary valve stenting. The first is the anchoring of the valve stent. It is essential to deliver the stent to the exact position and not displace it. A precise 3D structural design allows for better alignment of the stent and better adaptation to the RVOT and pulmonary valve annulus region at implantation.

The second is the choice of the stent material. Bare metal stents are unable to follow the growth of the child and have a limited ability to expand, which means that surgical re-intervention is required. Biodegradable stents have become an alternative to bare metal stents, with the most significant advantage of degradation leaving only endothelialized natural vessels with the potential for further growth. Teams worldwide have been working on designing biodegradable stents for children with CHD [102]. Illusicor stent (Tremedics Medical Devices LLC, Richland Hills, TX, USA) and 480 Biomedical stent (480 Biomedical Inc., Cambridge, MA, USA) have been developed as bioresorbable stents with preclinical experience for use in CHD [102-104]. The Zinc bioresorbable stent (ZeBRa stent, Pediastent LLC, Cleveland, OH, USA) is the latest biodegradable stent explicitly designed for CHD.

\section{Discussion}

TPVR is a safe and effective non-surgical treatment strategy for RVOT dysfunction. However, TRVR is still not available in approximately two-thirds of patients due to large RVOT diameters. Devices suitable for large RVOT diameters are currently under investigation and testing (Venus P valve, Medtronic Harmony). The largest transcatheter pulmonary valve prosthesis is the Edwards Sapien XT valve, a transcatheter aortic valve implant. It can be dilated to $31 \mathrm{~mm}$ without damaging the Sapien valve or using an Alterra Adaptive Prestent (Edwards Lifesciences, Irvine, CA, USA) [105]. In future work, an innovative valved stent must be developed to address these limitations. Until then, surgical treatment will remain the gold standard.

In addition to this, the issue of valve material deserves our attention. For young patients who need to be operated, multiple surgeries are to be avoided. Therefore, tissueengineered valves have been studied for more than 20 years as a solution to this problem. DHVs are an essential component of this research. Decellularized pulmonary valve homografts (DPVHs) have been used in the clinic, and the first fDPVHs have been shown to perform with spontaneous recellularization potential $[65,81]$. fDPVHs have demonstrated superior performance compared to $\mathrm{CHs}$ [82]. cDPVHs also showed promising results in terms of immunocompatibility, performance, and durability in the short term $[91,106]$. However, in an 8-10-year time period, it did not significantly reduce reoperation rates nor did it show better performance than $\mathrm{CH}$ and was comparable to $\mathrm{CHs}$ in terms of fibrosis, calcification, and the degree of recellularization [79,92,106,107].

In contrast, it has been shown that fresh DPVHs performed better than cryopreserved DPVHs [106], possibly because the hypothermic environment and decellularization procedure affected the original tissue structure and mechanical properties, thus affecting 
the endothelialization procedure. In addition, it has been shown that low-dose gamma radiation can severely affect the structural integrity of ECM [108].

With the development of multiphoton-induced autofluorescence and second harmonic generated imaging, it is possible to visualize the alterations of the ECM in frozen heart valve tissue [109]. It is well known that the formation of extracellular ice is a hazard to structural tissues and organs. In 1965, Farrant recommended replacing $60 \%$ of cell water with cryoprotectant to prevent freezing at temperatures below $-70{ }^{\circ} \mathrm{C}$ [110]. As a result, several valve tissue preservation methods have been developed. To promote vitrification, a 55\% cryoprotectant formulation can be used to avoid ice formation below the glass transition temperature of the cryopreservation solution [111]. Brockbank et al. reported the use of an $83 \%$ cryoprotectant formulation: $83 \%$ of cryoprotectant formulation are stored at higher temperatures than $55 \%$ cryoprotectant formulation and cut without the risk of ice formation. This method is called ice-free cryopreservation, and the study showed that there was no significant difference in material properties, ECM component integrity, and cell viability of porcine valve tissue stored under $83 \%$ cryoprotectant solution at $-80{ }^{\circ} \mathrm{C}$ compared to $-135{ }^{\circ} \mathrm{C}$ vitrification cryopreservation [112]. However, cryoprotectants in high concentrations are potentially toxic, so long-term studies are still needed to determine their safety.

While other storage methods such as glutaraldehyde [113], glycerol [114], etc., have been reported, there is no consensus so far on the best storage strategies to ensure the quality of decellularized TEHV.

Therefore, it is essential to investigate cryopreservation techniques and optimize the decellularization and sterilization processes to protect homograft stability and remodeling after this step.

The lack of homografts has prompted researchers to search for new polymeric valve materials. In preclinical studies, polymeric valves have shown promising early function, implantation remodeling, and endothelialization potential [115-117]. However, they are still not being used in clinical applications. The reasons for this may be manifold; Firstly, their long-term safety and efficacy have not yet been established. Secondly, the whole process, both technically and logistically, is complex. Finally, differences between donor-todonor may lead to inconsistent and uncontrolled leaflet thickening and shortening of the final product, resulting in valve insufficiency [118]. Out of these reasons, decellularized heart valves are more favorable than synthetic ones at the time [81,82].

In situ tissue engineering has received much attention, is a simple process compared to in vitro re-cellularization and is designed to promote host cell adhesion and tissue formation. However, in situ tissue engineering is more dependent on the recipient's regenerative potential. The ideal in situ TEHV tissue should have the ability to selectively control host cell aggregation and adhesion, as well as the ability to directionally differentiate while controlling the onset of degradation until near-natural, functional tissue emerges [119].

\section{Summary and Prospects}

TPVR has emerged as a safe and effective therapy for RVOT dysfunction. The development of tissue engineering has solved already some problems. Nevertheless, there are still some issues that limit its indications and long-term prognosis.

Therefore, new designs of tissue-engineered bioresorbable valved stents and the search for more suitable valve material and, more importantly, combining the two technologies with each other will be the focus in the near future.

Author Contributions: Conceptualization, G.L. and T.P.; methodology, Z.X., J.S. (Jette Seiler), S.N.G., O.J.M.; validation, Z.X, G.L., T.P., and D.F.; formal analysis, Z.X.; investigation, T.P. and J.-H.H.; resources, G.L.; data curation, Z.X., J.S. (Jette Seiler); writing-original draft preparation, Z.X. and T.P.; writing-review and editing, T.P., J.S. (Janarthanan Sathananthan), S.S. and A.H.; visualization, J.-H.H.; supervision, A.U., G.L. and Z.X.; project administration, Z.X., G.L., D.F. and T.P.; funding and acquisition, G.L. All authors have read and agreed to the published version of the manuscript. 
Funding: Financial support was received from the German Centre for Cardiovascular Research (DZHK; 81Z07002020) and the German Foundation of Heart Research (DSHF; F/12/17).

Institutional Review Board Statement: The study procedures were approved by the ethics committee of the Medical Faculty of Medicine of the Kiel University, Germany (D522/16).

Conflicts of Interest: All authors declare no conflicts of interest.

$\begin{array}{ll}\text { Abbreviations } \\ \text { CHD } & \text { Congenital heart disease } \\ \text { RVOT } & \text { Right ventricular outflow tract } \\ \text { TPVR } & \text { Transcatheter pulmonary valve replacement } \\ \text { ECM } & \text { Extracellular matrix } \\ \text { TEHV } & \text { Tissue-engineered heart valve } \\ \text { DHVs } & \text { Decellularized heart valves } \\ \text { dsDNA } & \text { Double-stranded DNA } \\ \text { DAPI } & 4^{\prime} \text {,6-diamidino-2-phenylindole } \\ \text { H\&E } & \text { Hematoxylin-eosin } \\ \text { MSC } & \text { Mesenchymal stem cells } \\ \text { VEGF } & \text { Vascular endothelial growth factor } \\ \text { DPHs } & \text { Decellularized pulmonary homografts } \\ \text { CH } & \text { Cryopreserved homograft } \\ \text { BJV } & \text { Bovine jugular vein } \\ \text { SDC } & \text { Sodium deoxycholate } \\ \text { SDS } & \text { Sodium dodecyl sulfate } \\ \text { EDTA } & \text { Ethylenediaminetetraacetic acid } \\ \text { cDPVH } & \text { Cryopreserved decellularized pulmonary valve homograft } \\ \text { fDPVH } & \text { Fresh decellularized pulmonary valve homograft } \\ \text { PCU } & \text { Polycarbonate urethane } \\ \text { DPVHs } & \text { Decellularized pulmonary valve homografts } \\ & \end{array}$

\section{References}

1. Baumgartner, H.; De Backer, J.; Babu-Narayan, S.V.; Budts, W.; Chessa, M.; Diller, G.P.; Lung, B.; Kluin, J.; Lang, I.M.; Meijboom, F.; et al. 2020 ESC Guidelines for the management of adult congenital heart disease. Eur. Heart J. 2021, 42, 563-645. [CrossRef]

2. McElhinney, D.B.; Hennesen, J.T. The Melody $(\mathrm{R})$ valve and Ensemble(R) delivery system for transcatheter pulmonary valve replacement. Ann. N. Y. Acad. Sci. 2013, 1291, 77-85. [CrossRef] [PubMed]

3. Murphy, J.G.; Gersh, B.J.; Mair, D.D.; Fuster, V.; McGoon, M.D.; Ilstrup, D.M.; McGoon, D.C.; Kirklin, J.W.; Danielson, G.K. Long-term outcome in patients undergoing surgical repair of tetralogy of Fallot. N. Engl. J. Med. 1993, 329, 593-599. [CrossRef] [PubMed]

4. Yuan, S.-M.; Mishaly, D.; Shinfeld, A.; Raanani, E. Right ventricular outflow tract reconstruction: Valved conduit of choice and clinical outcomes. J. Cardiovasc. Med. 2008, 9, 327-337. [CrossRef] [PubMed]

5. Brown, J.W.; Ruzmetov, M.; Rodefeld, M.D.; Vijay, P.; Turrentine, M.W. Right ventricular outflow tract reconstruction with an allograft conduit in non-ross patients: Risk factors for allograft dysfunction and failure. Ann. Thorac. Surg. 2005, 80, 655-663, discussion 663-654. [CrossRef]

6. Wells, W.J.; Arroyo, H., Jr.; Bremner, R.M.; Wood, J.; Starnes, V.A. Homograft conduit failure in infants is not due to somatic outgrowth. J. Thorac. Cardiovasc. Surg. 2002, 124, 88-96. [CrossRef]

7. $\quad$ Lange, R.; Weipert, J.; Homann, M.; Mendler, N.; Paek, S.-U.; Holper, K.; Meisner, H. Performance of allografts and xenografts for right ventricular outflow tract reconstruction. Ann. Thorac. Surg. 2001, 71, S365-S367. [CrossRef]

8. Kanter, K.R.; Budde, J.M.; Parks, W.J.; Tam, V.K.; Sharma, S.; Williams, W.H.; Fyfe, D.A. One hundred pulmonary valve replacements in children after relief of right ventricular outflow tract obstruction. Ann. Thorac. Surg. 2002, 73, 1801-1807. [CrossRef]

9. Bonhoeffer, P.; Boudjemline, Y.; Saliba, Z.; Merckx, J.; Aggoun, Y.; Bonnet, D.; Acar, P.; Le Bidois, J.; Sidi, D.; Kachaner, J. Percutaneous replacement of pulmonary valve in a right-ventricle to pulmonary-artery prosthetic conduit with valve dysfunction. Lancet 2000, 356, 1403-1405. [CrossRef]

10. Zahn, E.M.; Hellenbrand, W.E.; Lock, J.E.; McElhinney, D.B. Implantation of the Melody transcatheter pulmonary valve in patients with a dysfunctional right ventricular outflow tract conduit: Early results from the US clinical trial. J. Am. Coll. Cardiol. 2009, 54, 1722-1729. [CrossRef] 
11. Boethig, D.; Avsar, M.; Bauer, U.M.; Sarikouch, S.; Beerbaum, P.; Berger, F.; Cesnjevar, R.; Dähnert, I.; Dittrich, S.; Ewert, P. Pulmonary valve prostheses: Patient's lifetime procedure load and durability. Evaluation of the German National Register for Congenital Heart Defects. Interact. CardioVasc. Thorac. Surg. 2021, ivab233. [CrossRef]

12. Schievano, S.; Coats, L.; Migliavacca, F.; Norman, W.; Frigiola, A.; Deanfield, J.; Bonhoeffer, P.; Taylor, A.M. Variations in right ventricular outflow tract morphology following repair of congenital heart disease: Implications for percutaneous pulmonary valve implantation. J. Cardiovasc. Magn. Reson. 2007, 9, 687-695. [CrossRef] [PubMed]

13. Basude, S.; Hein, C.; Curtis, S.; Clark, A.; Trinder, J. Low-molecular-weight heparin or warfarin for anticoagulation in pregnant women with mechanical heart valves: What are the risks? A retrospective observational study. BJOG Int. J. Obstet. Gynaecol. 2012, 119, 1008-1013. [CrossRef] [PubMed]

14. Schoen, F.J.; Levy, R.J. Calcification of tissue heart valve substitutes: Progress toward understanding and prevention. Ann. Thorac. Surg. 2005, 79, 1072-1080. [CrossRef]

15. Jordan, J.E.; Williams, J.K.; Lee, S.-J.; Raghavan, D.; Atala, A.; Yoo, J.J. Bioengineered self-seeding heart valves. J. Thorac. Cardiovasc. Surg. 2012, 143, 201-208. [CrossRef]

16. Stassen, O.; Muylaert, D.; Bouten, C.V.; Hjortnaes, J. Current challenges in translating tissue-engineered heart valves. Curr. Treat. Options Cardiovasc. Med. 2017, 19, 71. [CrossRef] [PubMed]

17. Nii, T.; Katayama, Y. Biomaterial-Assisted regenerative medicine. Int. J. Mol. Sci. 2021, 22, 8657. [CrossRef] [PubMed]

18. Yue, S.; He, H.; Li, B.; Hou, T. Hydrogel as a biomaterial for bone tissue engineering: A review. Nanomaterials 2020, $10,1511$. [CrossRef]

19. Groeber, F.; Holeiter, M.; Hampel, M.; Hinderer, S.; Schenke-Layland, K. Skin tissue engineering-in vivo and in vitro applications. Adv. Drug Deliv. Rev. 2011, 63, 352-366. [CrossRef]

20. Nii, T.; Makino, K.; Tabata, Y. Three-dimensional culture system of cancer cells combined with biomaterials for drug screening. Cancers 2020, 12, 2754. [CrossRef]

21. Peña, B.; Laughter, M.; Jett, S.; Rowland, T.J.; Taylor, M.R.; Mestroni, L.; Park, D. Injectable hydrogels for cardiac tissue engineering. Macromol. Biosci. 2018, 18, 1800079. [CrossRef]

22. Mitsui, R.; Matsukawa, M.; Nakagawa, K.; Isomura, E.; Kuwahara, T.; Nii, T.; Tanaka, S.; Tabata, Y. Efficient cell transplantation combining injectable hydrogels with control release of growth factors. Regen. Ther. 2021, 18, 372-383. [CrossRef]

23. Alkashkari, W.; Albugami, S.; Abbadi, M.; Niyazi, A.; Alsubei, A.; Hijazi, Z.M. Transcatheter pulmonary valve replacement in pediatric patients. Expert Rev. Med. Devices 2020, 17, 541-554. [CrossRef] [PubMed]

24. Cheatham, J.P.; Hellenbrand, W.E.; Zahn, E.M.; Jones, T.K.; Berman, D.P.; Vincent, J.A.; McElhinney, D.B. Clinical and hemodynamic outcomes up to 7 years after transcatheter pulmonary valve replacement in the US melody valve investigational device exemption trial. Circulation 2015, 131, 1960-1970. [CrossRef] [PubMed]

25. Kenny, D.; Hijazi, Z.M.; Kar, S.; Rhodes, J.; Mullen, M.; Makkar, R.; Shirali, G.; Fogel, M.; Fahey, J.; Heitschmidt, M.G. Percutaneous implantation of the Edwards SAPIEN transcatheter heart valve for conduit failure in the pulmonary position: Early phase 1 results from an international multicenter clinical trial. J. Am. Coll. Cardiol. 2011, 58, 2248-2256. [CrossRef]

26. Odemis, E.; Guzeltas, A.; Saygi, M.; Ozyilmaz, I.; Momenah, T.; Bakir, I. Percutaneous Pulmonary Valve Implantation Using E dwards SAPIEN T ranscatheter $\mathrm{H}$ eart V alve in Different Types of Conduits: Initial Results of a Single Center Experience. Congenit. Heart Dis. 2013, 8, 411-417.

27. Boshoff, D.E.; Cools, B.L.; Heying, R.; Troost, E.; Kefer, J.; Budts, W.; Gewillig, M. Off-label use of percutaneous pulmonary valved stents in the right ventricular outflow tract: Time to rewrite the label? Catheter. Cardiovasc. Interv. 2013, 81, 987-995. [CrossRef] [PubMed]

28. Meadows, J.J.; Moore, P.M.; Berman, D.P.; Cheatham, J.P.; Cheatham, S.L.; Porras, D.; Gillespie, M.J.; Rome, J.J.; Zahn, E.M.; McElhinney, D.B. Use and performance of the Melody Transcatheter Pulmonary Valve in native and postsurgical, nonconduit right ventricular outflow tracts. Circ. Cardiovasc. Interv. 2014, 7, 374-380. [CrossRef]

29. Gillespie, M.J.; Rome, J.J.; Levi, D.S.; Williams, R.J.; Rhodes, J.F.; Cheatham, J.P.; Hellenbrand, W.E.; Jones, T.K.; Vincent, J.A.; Zahn, E.M. Melody valve implant within failed bioprosthetic valves in the pulmonary position: A multicenter experience. Circ. Cardiovasc. Interv. 2012, 5, 862-870. [CrossRef]

30. Schievano, S.; Taylor, A.M.; Capelli, C.; Coats, L.; Walker, F.; Lurz, P.; Nordmeyer, J.; Wright, S.; Khambadkone, S.; Tsang, V. First-in-man implantation of a novel percutaneous valve: A new approach to medical device development. EuroInterv. J. EuroPCR Collab. Work. Group Interv. Cardiol. Eur. Soc. Cardiol. 2010, 5, 745-750. [CrossRef]

31. Cao, Q.L.; Kenny, D.; Zhou, D.; Pan, W.; Guan, L.; Ge, J.; Hijazi, Z.M. Early clinical experience with a novel self-expanding percutaneous stent-valve in the native right ventricular outflow tract. Catheter. Cardiovasc. Interv. 2014, 84, 1131-1137. [CrossRef]

32. Promphan, W.; Prachasilchai, P.; Siripornpitak, S.; Qureshi, S.A.; Layangool, T. Percutaneous pulmonary valve implantation with the Venus P-valve: Clinical experience and early results. Cardiol. Young 2016, 26, 698-710. [CrossRef]

33. Basquin, A.; Pineau, E.; Galmiche, L.; Bonnet, D.; Sidi, D.; Boudjemline, Y. Transcatheter valve insertion in a model of enlarged right ventricular outflow tracts. J. Thorac. Cardiovasc. Surg. 2010, 139, 198-208. [CrossRef]

34. Amahzoune, B.; Szymansky, C.; Fabiani, J.-N.; Zegdi, R. A new endovascular size reducer for large pulmonary outflow tract. Eur. J. Cardio-Thorac. Surg. 2010, 37, 730-732. [CrossRef] 
35. Gillespie, M.J.; Dori, Y.; Harris, M.A.; Sathanandam, S.; Glatz, A.C.; Rome, J.J. Bilateral branch pulmonary artery melody valve implantation for treatment of complex right ventricular outflow tract dysfunction in a high-risk patient. Circ. Cardiovasc. Interv. 2011, 4, e21-e23. [CrossRef] [PubMed]

36. Boudjemline, Y.; Legendre, A.; Ladouceur, M.; Boughenou, M.-F.; Patel, M.; Bonnet, D.; Iserin, L. Branch pulmonary artery jailing with a bare metal stent to anchor a transcatheter pulmonary valve in patients with patched large right ventricular outflow tract. Circ. Cardiovasc. Interv. 2012, 5, e22-e25. [CrossRef] [PubMed]

37. Ruiz, C.E.; Pasala, T.K. Are We Ready for Transcatheter Pulmonary Valve Replacement in Native Right Ventricular Outflow Tract? American College of Cardiology Foundation: Washington, DC, USA, 2018.

38. Masoumi, N.; Annabi, N.; Assmann, A.; Larson, B.L.; Hjortnaes, J.; Alemdar, N.; Kharaziha, M.; Manning, K.B.; Mayer, J.E., Jr.; Khademhosseini, A. Tri-layered elastomeric scaffolds for engineering heart valve leaflets. Biomaterials 2014, 35, 7774-7785. [CrossRef]

39. Crapo, P.M.; Gilbert, T.W.; Badylak, S.F. An overview of tissue and whole organ decellularization processes. Biomaterials 2011, 32, 3233-3243. [CrossRef]

40. Koolbergen, D.R.; Hazekamp, M.G.; Kurvers, M.; de Heer, E.; Cornelisse, C.J.; Huysmans, H.A.; Bruijn, J.A. Tissue chimerism in human cryopreserved homograft valve explants demonstrated by in situ hybridization. Ann. Thorac. Surg. 1998, 66, S225-S232. [CrossRef]

41. Lehner, G.; Fischlein, T.; Baretton, G.; Murphy, J.; Reichart, B. Endothelialized biological heart valve prostheses in the non-human primate model. Eur. J. Cardio-Thorac. Surg. 1997, 11, 498-504. [CrossRef]

42. Dohmen, P.M.; Lembcke, A.; Hotz, H.; Kivelitz, D.; Konertz, W.F. Ross operation with a tissue-engineered heart valve. The Ann. Thorac. Surg. 2002, 74, 1438-1442. [CrossRef]

43. Elkins, R.C.; Dawson, P.E.; Goldstein, S.; Walsh, S.P.; Black, K.S. Decellularized human valve allografts. Ann. Thorac. Surg. 2001, 71, S428-S432. [CrossRef]

44. Grauss, R.W.; Hazekamp, M.G.; Oppenhuizen, F.; van Munsteren, C.J.; Gittenberger-de Groot, A.C.; DeRuiter, M.C. Histological evaluation of decellularised porcine aortic valves: Matrix changes due to different decellularisation methods. Eur. J. Cardio-Thorac. Surg. 2005, 27, 566-571. [CrossRef] [PubMed]

45. Bin, F.; Yinglong, L.; Nin, X.; Kai, F.; Laifeng, S.; Xiaodong, Z. Construction of tissue-engineered homograft bioprosthetic heart valves in vitro. ASAIO J. 2006, 52, 303-309. [CrossRef] [PubMed]

46. Rieder, E.; Kasimir, M.-T.; Silberhumer, G.; Seebacher, G.; Wolner, E.; Simon, P.; Weigel, G. Decellularization protocols of porcine heart valves differ importantly in efficiency of cell removal and susceptibility of the matrix to recellularization with human vascular cells. J. Thorac. Cardiovasc. Surg. 2004, 127, 399-405. [CrossRef]

47. Rieder, E.; Seebacher, G.; Kasimir, M.-T.; Eichmair, E.; Winter, B.; Dekan, B.; Wolner, E.; Simon, P.; Weigel, G. Tissue engineering of heart valves: Decellularized porcine and human valve scaffolds differ importantly in residual potential to attract monocytic cells. Circulation 2005, 111, 2792-2797. [CrossRef]

48. Dainese, L.; Guarino, A.; Burba, I.; Esposito, G.; Pompilio, G.; Polvani, G.; Rossini, A. Heart valve engineering: Decellularized aortic homograft seeded with human cardiac stromal cells. J. Heart Valve Dis. 2012, 21, 125.

49. Knight, R.L.; Booth, C.; Wilcox, H.E.; Fisher, J.; Ingham, E. Tissue engineering of cardiac valves: Re-seeding of acellular porcine aortic valve matrices with human mesenchymal progenitor cells. J. Heart Valve Dis. 2005, 14, 806-813. [PubMed]

50. Zeltinger, J.; Landeen, L.K.; Alexander, H.G.; Kidd, I.D.; Sibanda, B. Development and characterization of tissue-engineered aortic valves. Tissue Eng. 2001, 7, 9-22. [CrossRef]

51. Yuan, L.; Sakamoto, N.; Song, G.; Sato, M. High-level shear stress stimulates endothelial differentiation and VEGF secretion by human mesenchymal stem cells. Cell. Mol. Bioeng. 2013, 6, 220-229. [CrossRef]

52. Pankajakshan, D.; Kansal, V.; Agrawal, D.K. In vitro differentiation of bone marrow derived porcine mesenchymal stem cells to endothelial cells. J. Tissue Eng. Regen. Med. 2013, 7, 911-920. [CrossRef] [PubMed]

53. Converse, G.L.; Buse, E.E.; Neill, K.R.; McFall, C.R.; Lewis, H.N.; VeDepo, M.C.; Quinn, R.W.; Hopkins, R.A. Design and efficacy of a single-use bioreactor for heart valve tissue engineering. J. Biomed. Mater. Res. Part B Appl. Biomater. 2017, 105, 249-259. [CrossRef] [PubMed]

54. Vincentelli, A.; Wautot, F.; Juthier, F.; Fouquet, O.; Corseaux, D.; Marechaux, S.; Le Tourneau, T.; Fabre, O.; Susen, S.; Van Belle, E. In vivo autologous recellularization of a tissue-engineered heart valve: Are bone marrow mesenchymal stem cells the best candidates? J. Thorac. Cardiovasc. Surg. 2007, 134, 424-432. [CrossRef]

55. Sales, V.L.; Mettler, B.A.; Engelmayr, G.C., Jr.; Aikawa, E.; Bischoff, J.; Martin, D.P.; Exarhopoulos, A.; Moses, M.A.; Schoen, F.J.; Sacks, M.S. Endothelial progenitor cells as a sole source for ex vivo seeding of tissue-engineered heart valves. Tissue Eng. Part $A$ 2010, 16, 257-267. [CrossRef]

56. Frid, M.G.; Kale, V.A.; Stenmark, K.R. Mature vascular endothelium can give rise to smooth muscle cells via endothelialmesenchymal transdifferentiation: In vitro analysis. Circ. Res. 2002, 90, 1189-1196. [CrossRef]

57. Hopkins, R.A.; Bert, A.A.; Hilbert, S.L.; Quinn, R.W.; Brasky, K.M.; Drake, W.B.; Lofland, G.K. Bioengineered human and allogeneic pulmonary valve conduits chronically implanted orthotopically in baboons: Hemodynamic performance and immunologic consequences. J. Thorac. Cardiovasc. Surg. 2013, 145, 1098-1107.e1093. [CrossRef] [PubMed] 
58. Boldt, J.; Lutter, G.; Pohanke, J.; Fischer, G.; Schoettler, J.; Cremer, J.; Metzner, A. Percutaneous tissue-engineered pulmonary valved stent implantation: Comparison of bone marrow-derived CD133+-cells and cells obtained from carotid artery. Tissue Eng. Part C Methods 2013, 19, 363-374. [CrossRef]

59. Lichtenberg, A.; Tudorache, I.; Cebotari, S.; Ringes-Lichtenberg, S.; Sturz, G.; Hoeffler, K.; Hurscheler, C.; Brandes, G.; Hilfiker, A.; Haverich, A. In vitro re-endothelialization of detergent decellularized heart valves under simulated physiological dynamic conditions. Biomaterials 2006, 27, 4221-4229. [CrossRef]

60. Lichtenberg, A.; Cebotari, S.; Tudorache, I.; Sturz, G.; Winterhalter, M.; Hilfiker, A.; Haverich, A. Flow-dependent reendothelialization of tissue-engineered heart valves. J. Heart Valve Dis. 2006, 15, 287.

61. Lichtenberg, A.; Tudorache, I.; Cebotari, S.; Suprunov, M.; Tudorache, G.; Goerler, H.; Park, J.-K.; Hilfiker-Kleiner, D.; RingesLichtenberg, S.; Karck, M. Preclinical testing of tissue-engineered heart valves re-endothelialized under simulated physiological conditions. Circulation 2006, 114, I-559-I-565. [CrossRef]

62. Tudorache, I.; Calistru, A.; Baraki, H.; Meyer, T.; Höffler, K.; Sarikouch, S.; Bara, C.; Görler, A.; Hartung, D.; Hilfiker, A. Orthotopic replacement of aortic heart valves with tissue-engineered grafts. Tissue Eng. Part A 2013, 19, 1686-1694. [CrossRef]

63. Schenke-Layland, K.; Opitz, F.; Gross, M.; Döring, C.; Halbhuber, K.; Schirrmeister, F.; Wahlers, T.; Stock, U. Complete dynamic repopulation of decellularized heart valves by application of defined physical signals-An in vitro study. Cardiovasc. Res. 2003, 60, 497-509. [CrossRef]

64. Kajbafzadeh, A.-M.; Tafti, S.H.A.; Mokhber-Dezfooli, M.-R.; Khorramirouz, R.; Sabetkish, S.; Sabetkish, N.; Rabbani, S.; Tavana, H.; Mohseni, M.J. Aortic valve conduit implantation in the descending thoracic aorta in a sheep model: The outcomes of pre-seeded scaffold. Int. J. Surg. 2016, 28, 97-105. [CrossRef]

65. Cebotari, S.; Lichtenberg, A.; Tudorache, I.; Hilfiker, A.; Mertsching, H.; Leyh, R.; Breymann, T.; Kallenbach, K.; Maniuc, L.; Batrinac, A. Clinical application of tissue engineered human heart valves using autologous progenitor cells. Circulation 2006, 114, I-132-I-137. [CrossRef]

66. Iop, L.; Gerosa, G. Guided tissue regeneration in heart valve replacement: From preclinical research to first-in-human trials. BioMed Res. Int. 2015, 2015, 432901. [CrossRef]

67. James, I.A.; Yi, T.; Tara, S.; Best, C.A.; Stuber, A.J.; Shah, K.V.; Austin, B.F.; Sugiura, T.; Lee, Y.-U.; Lincoln, J. Hemodynamic characterization of a mouse model for investigating the cellular and molecular mechanisms of neotissue formation in tissueengineered heart valves. Tissue Eng. Part C Methods 2015, 21, 987-994. [CrossRef]

68. Baraki, H.; Tudorache, I.; Braun, M.; Höffler, K.; Görler, A.; Lichtenberg, A.; Bara, C.; Calistru, A.; Brandes, G.; HewickerTrautwein, M. Orthotopic replacement of the aortic valve with decellularized allograft in a sheep model. Biomaterials 2009, 30, 6240-6246. [CrossRef] [PubMed]

69. Hopkins, R.A.; Jones, A.L.; Wolfinbarger, L.; Moore, M.A.; Bert, A.A.; Lofland, G.K. Decellularization reduces calcification while improving both durability and 1-year functional results of pulmonary homograft valves in juvenile sheep. J. Thorac. Cardiovasc. Surg. 2009, 137, 907-913.e904. [CrossRef]

70. Quinn, R.W.; Hilbert, S.L.; Bert, A.A.; Drake, B.W.; Bustamante, J.A.; Fenton, J.E.; Moriarty, S.J.; Neighbors, S.L.; Lofland, G.K.; Hopkins, R.A. Performance and morphology of decellularized pulmonary valves implanted in juvenile sheep. Ann. Thorac. Surg. 2011, 92, 131-137. [CrossRef] [PubMed]

71. Leyh, R.G.; Wilhelmi, M.; Rebe, P.; Fischer, S.; Kofidis, T.; Haverich, A.; Mertsching, H. In vivo repopulation of xenogeneic and allogeneic acellular valve matrix conduits in the pulmonary circulation. Ann. Thorac. Surg. 2003, 75, 1457-1463. [CrossRef]

72. Paniagua Gutierrez, J.R.; Berry, H.; Korossis, S.; Mirsadraee, S.; Lopes, S.V.; da Costa, F.; Kearney, J.; Watterson, K.; Fisher, J.; Ingham, E. Regenerative potential of low-concentration SDS-decellularized porcine aortic valved conduits in vivo. Tissue Eng. Part A 2015, 21, 332-342. [CrossRef]

73. Juthier, F.; Vincentelli, A.; Gaudric, J.; Corseaux, D.; Fouquet, O.; Calet, C.; Le Tourneau, T.; Soenen, V.; Zawadzki, C.; Fabre, O. Decellularized heart valve as a scaffold for in vivo recellularization: Deleterious effects of granulocyte colony-stimulating factor. J. Thorac. Cardiovasc. Surg. 2006, 131, 843-852. [CrossRef]

74. Honge, J.L.; Funder, J.; Hansen, E.; Dohmen, P.M.; Konertz, W.; Hasenkam, J.M. Recellularization of aortic valves in pigs. Eur. J. Cardio-Thorac. Surg. 2011, 39, 829-834. [CrossRef]

75. Takagi, K.; Fukunaga, S.; Nishi, A.; Shojima, T.; Yoshikawa, K.; Hori, H.; Akashi, H.; Aoyagi, S. In vivo recellularization of plain decellularized xenografts with specific cell characterization in the systemic circulation: Histological and immunohistochemical study. Artif. Organs 2006, 30, 233-241. [CrossRef]

76. Goldstein, S.; Clarke, D.R.; Walsh, S.P.; Black, K.S.; O’Brien, M.F. Transpecies heart valve transplant: Advanced studies of a bioengineered xeno-autograft. Ann. Thorac. Surg. 2000, 70, 1962-1969. [CrossRef]

77. Iwai, S.; Torikai, K.; Coppin, C.M.; Sawa, Y. Minimally immunogenic decellularized porcine valve provides in situ recellularization as a stentless bioprosthetic valve. J. Artif. Organs 2007, 10, 29-35. [CrossRef] [PubMed]

78. Simon, P.; Kasimir, M.; Seebacher, G.; Weigel, G.; Ullrich, R.; Salzer-Muhar, U.; Rieder, E.; Wolner, E. Early failure of the tissue engineered porcine heart valve SYNERGRAFT®in pediatric patients. Eur. J. Cardio-Thorac. Surg. 2003, 23, 1002-1006. [CrossRef]

79. Konertz, W.; Angeli, E.; Tarusinov, G.; Christ, T.; Kroll, J.; Dohmen, P.M.; Krogmann, O.; Franzbach, B.; Pace Napoleone, C.; Gargiulo, G. Right ventricular outflow tract reconstruction with decellularized porcine xenografts in patients with congenital heart disease. J. Heart Valve Dis. 2011, 20, 341. 
80. Voges, I.; Bräsen, J.H.; Entenmann, A.; Scheid, M.; Scheewe, J.; Fischer, G.; Hart, C.; Andrade, A.; Pham, H.M.; Kramer, H.-H. Adverse results of a decellularized tissue-engineered pulmonary valve in humans assessed with magnetic resonance imaging. Eur. J. Cardio-Thorac. Surg. 2013, 44, e272-e279. [CrossRef]

81. Sarikouch, S.; Horke, A.; Tudorache, I.; Beerbaum, P.; Westhoff-Bleck, M.; Boethig, D.; Repin, O.; Maniuc, L.; Ciubotaru, A.; Haverich, A. Decellularized fresh homografts for pulmonary valve replacement: A decade of clinical experience. Eur. J. Cardio-Thorac. Surg. 2016, 50, 281-290. [CrossRef] [PubMed]

82. Boethig, D.; Horke, A.; Hazekamp, M.; Meyns, B.; Rega, F.; Van Puyvelde, J.; Hübler, M.; Schmiady, M.; Ciubotaru, A.; Stellin, G. A European study on decellularized homografts for pulmonary valve replacement: Initial results from the prospective ESPOIR Trial and ESPOIR Registry data. Eur. J. Cardio-Thorac. Surg. 2019, 56, 503-509. [CrossRef] [PubMed]

83. Cebotari, S.; Tudorache, I.; Ciubotaru, A.; Boethig, D.; Sarikouch, S.; Goerler, A.; Lichtenberg, A.; Cheptanaru, E.; Barnaciuc, S.; Cazacu, A. Use of fresh decellularized allografts for pulmonary valve replacement may reduce the reoperation rate in children and young adults: Early report. Circulation 2011, 124, S115-S123. [CrossRef] [PubMed]

84. Ruzmetov, M.; Shah, J.J.; Geiss, D.M.; Fortuna, R.S. Decellularized versus standard cryopreserved valve allografts for right ventricular outflow tract reconstruction: A single-institution comparison. J. Thorac. Cardiovasc. Surg. 2012, 143, 543-549. [CrossRef]

85. Brown, J.W.; Elkins, R.C.; Clarke, D.R.; Tweddell, J.S.; Huddleston, C.B.; Doty, J.R.; Fehrenbacher, J.W.; Takkenberg, J.J. Performance of the CryoValve SG human decellularized pulmonary valve in 342 patients relative to the conventional CryoValve at a mean follow-up of four years. J. Thorac. Cardiovasc. Surg. 2010, 139, 339-348. [CrossRef]

86. Bibevski, S.; Ruzmetov, M.; Fortuna, R.S.; Turrentine, M.W.; Brown, J.W.; Ohye, R.G. Performance of SynerGraft decellularized pulmonary allografts compared with standard cryopreserved allografts: Results from multiinstitutional data. Ann. Thorac. Surg. 2017, 103, 869-874. [CrossRef]

87. Yankah, A.; Wottge, H.-U.; Muller-Hermelink, H.; Feller, A.; Lange, P.; Wessel, U.; Dreyer, H.; Bernhard, A.; Müller-Ruchholtz, W. Transplantation of aortic and pulmonary allografts, enhanced viability of endothelial cells by cryopreservation, importance of histocompatibility. J. Card. Surg. 1987, 2, 209-220. [CrossRef]

88. Cebotari, S.; Tudorache, I.; Jaekel, T.; Hilfiker, A.; Dorfman, S.; Ternes, W.; Haverich, A.; Lichtenberg, A. Detergent decellularization of heart valves for tissue engineering: Toxicological effects of residual detergents on human endothelial cells. Artif. Organs 2010 34, 206-210. [CrossRef]

89. Bobylev, D.; Sarikouch, S.; Tudorache, I.; Cvitkovic, T.; Söylen, B.; Boethig, D.; Theodoridis, K.; Bertram, H.; Beerbaum, P.; Haverich, A. Double semilunar valve replacement in complex congenital heart disease using decellularized homografts. Interact. Cardiovasc. Thorac. Surg. 2019, 28, 151-157. [CrossRef]

90. Dohmen, P.M.; Lembcke, A.; Holinski, S.; Pruss, A.; Konertz, W. Ten years of clinical results with a tissue-engineered pulmonary valve. Ann. Thorac. Surg. 2011, 92, 1308-1314. [CrossRef]

91. Brown, J.W.; Ruzmetov, M.; Eltayeb, O.; Rodefeld, M.D.; Turrentine, M.W. Performance of SynerGraft decellularized pulmonary homograft in patients undergoing a Ross procedure. Ann. Thorac. Surg. 2011, 91, 416-423. [CrossRef]

92. Burch, P.T.; Kaza, A.K.; Lambert, L.M.; Holubkov, R.; Shaddy, R.E.; Hawkins, J.A. Clinical performance of decellularized cryopreserved valved allografts compared with standard allografts in the right ventricular outflow tract. Ann. Thorac. Surg. 2010, 90, 1301-1306. [CrossRef] [PubMed]

93. Dohmen, P.M.; Lembcke, A.; Holinski, S.; Kivelitz, D.; Braun, J.P.; Pruss, A.; Konertz, W. Mid-term clinical results using a tissue-engineered pulmonary valve to reconstruct the right ventricular outflow tract during the Ross procedure. Ann. Thorac. Surg. 2007, 84, 729-736. [CrossRef] [PubMed]

94. Hawkins, J.A.; Hillman, N.D.; Lambert, L.M.; Jones, J.; Di Russo, G.B.; Profaizer, T.; Fuller, T.C.; Minich, L.L.; Williams, R.V.; Shaddy, R.E. Immunogenicity of decellularized cryopreserved allografts in pediatric cardiac surgery: Comparison with standard cryopreserved allografts. J. Thorac. Cardiovasc. Surg. 2003, 126, 247-252. [CrossRef]

95. Kumar, M.; Turrentine, M.W.; Rodefeld, M.D.; Bell, T.; Brown, J.W. Right ventricular outflow tract reconstruction with a polytetrafluoroethylene monocusp valve: A 20-year experience. Semin. Thorac. Cardiovasc. Surg. 2016, 28, 463-470. [CrossRef]

96. Nistal, F.; García-Martínez, V.; Arbe, E.; Fernàndez, D.; Artiñano, E.; Mazorra, F.; Gallo, I. In vivo experimental assessment of polytetrafluoroethylene trileaflet heart valve prosthesis. J. Thorac. Cardiovasc. Surg. 1990, 99, 1074-1081. [CrossRef]

97. Lutter, G.; Topal, A.; Hansen, J.H.; Haneya, A.; Santhanthan, J.; Freitag-Wolf, S.; Frank, D.; Puehler, T. Transcatheter pulmonary valve replacement: A new polycarbonate urethane valve. Eur. J. Cardio-Thorac. Surg. 2021, 59, 1048-1056. [CrossRef]

98. Aleksieva, G.; Hollweck, T.; Thierfelder, N.; Haas, U.; Koenig, F.; Fano, C.; Dauner, M.; Wintermantel, E.; Reichart, B.; Schmitz, C. Use of a special bioreactor for the cultivation of a new flexible polyurethane scaffold for aortic valve tissue engineering. Biomed. Eng. Online 2012, 11, 92. [CrossRef]

99. Mei, N.; Chen, G.; Zhou, P.; Chen, X.; Shao, Z.-Z.; Pan, L.-F.; Wu, C.-G. Biocompatibility of poly ( $\varepsilon$-caprolactone) scaffold modified by chitosan-The fibroblasts proliferation in vitro. J. Biomater. Appl. 2005, 19, 323-339. [CrossRef]

100. Lutter, G.; Metzner, A.; Jahnke, T.; Bombien, R.; Boldt, J.; Iino, K.; Cremer, J.; Stock, U.A. Percutaneous tissue-engineered pulmonary valved stent implantation. Ann. Thorac. Surg. 2010, 89, 259-263. [CrossRef]

101. Metzner, A.; Stock, U.A.; Iino, K.; Fischer, G.; Huemme, T.; Boldt, J.; Braesen, J.H.; Bein, B.; Renner, J.; Cremer, J. Percutaneous pulmonary valve replacement: Autologous tissue-engineered valved stents. Cardiovasc. Res. 2010, 88, 453-461. [CrossRef] 
102. Welch, T.R.; Nugent, A.; Veeram, S. Biodegradable stents for congenital heart disease. Interv. Cardiol. Clin. 2019, 8, 81-94. [CrossRef]

103. Herbert, C.E.; Veeram Reddy, S.; Welch, T.R.; Wang, J.; Richardson, J.A.; Forbess, J.M.; Nugent, A.W. Bench and initial preclinical results of a novel $8 \mathrm{~mm}$ diameter double opposed helical biodegradable stent. Catheter. Cardiovasc. Interv. 2016, 88, 902-911. [CrossRef]

104. Nugent, A.W.; Welch, T. Development of large diameter bioresorbable stents for congenital heart disease. J. Am. Coll. Cardiol. 2018, 71, A1353. [CrossRef]

105. Sathananthan, J.; Sellers, S.; Barlow, A.; Fraser, R.; Stanová, V.; Cheung, A.; Ye, J.; Alenezi, A.; Murdoch, D.J.; Hensey, M. Overexpansion of the SAPIEN 3 transcatheter heart valve: An ex vivo bench study. JACC Cardiovasc. Interv. 2018, 11, 1696-1705. [CrossRef]

106. Helder, M.R.; Kouchoukos, N.T.; Zehr, K.; Dearani, J.A.; Maleszewski, J.J.; Leduc, C.; Heins, C.N.; Schaff, H.V. Late durability of decellularized allografts for aortic valve replacement: A word of caution. J. Thorac. Cardiovasc. Surg. 2016, 152, 1197-1199. [CrossRef]

107. Sayk, F.; Bos, I.; Schubert, U.; Wedel, T.; Sievers, H.-H. Histopathologic findings in a novel decellularized pulmonary homograft: An autopsy study. Ann. Thorac. Surg. 2005, 79, 1755-1758. [CrossRef] [PubMed]

108. Helder, M.R.; Hennessy, R.S.; Spoon, D.B.; Tefft, B.J.; Witt, T.A.; Marler, R.J.; Pislaru, S.V.; Simari, R.D.; Stulak, J.M.; Lerman, A. Low-dose gamma irradiation of decellularized heart valves results in tissue injury in vitro and in vivo. Ann. Thorac. Surg. 2016, 101, 667-674. [CrossRef]

109. Schenke-Layland, K.; Xie, J.; Heydarkhan-Hagvall, S.; Hamm-Alvarez, S.F.; Stock, U.A.; Brockbank, K.G.; MacLellan, W.R. Optimized preservation of extracellular matrix in cardiac tissues: Implications for long-term graft durability. Ann. Thorac. Surg. 2007, 83, 1641-1650. [CrossRef] [PubMed]

110. Farrant, J. Mechanism of cell damage during freezing and thawing and its prevention. Nature 1965, 205, 1284-1287. [CrossRef]

111. Song, Y.C.; Khirabadi, B.S.; Lightfoot, F.; Brockbank, K.G.; Taylor, M.J. Vitreous cryopreservation maintains the function of vascular grafts. Nat. Biotechnol. 2000, 18, 296-299. [CrossRef]

112. Brockbank, K.G.; Wright, G.J.; Yao, H.; Greene, E.D.; Chen, Z.Z.; Schenke-Layland, K. Allogeneic heart valve storage above the glass transition at $-80^{\circ} \mathrm{C}$. Ann. Thorac. Surg. 2011, 91, 1829-1835. [CrossRef] [PubMed]

113. Salles, C.A.; Buffolo, E.; Andrade, J.C.; Palma, J.H.; Silva, R.R.; Santiago, R.; Casagrande, I.S.; Moreira, M.C.V. Mitral valve replacement with glutaraldehyde preserved aortic allografts. Eur. J. Cardio-Thorac. Surg. 1998, 13, 135-143. [CrossRef]

114. Parker, R.; Randev, R.; Wain, W.; Ross, D. Storage of heart valve allografts in glycerol with subsequent antibiotic sterilisation. Thorax 1978, 33, 638-645. [CrossRef]

115. Hoerstrup, S.P.; Sodian, R.; Daebritz, S.; Wang, J.; Bacha, E.A.; Martin, D.P.; Moran, A.M.; Guleserian, K.J.; Sperling, J.S.; Kaushal, S. Functional living trileaflet heart valves grown in vitro. Circulation 2000, 102, Iii-44-Iii-49. [CrossRef]

116. Gottlieb, D.; Kunal, T.; Emani, S.; Aikawa, E.; Brown, D.W.; Powell, A.J.; Nedder, A.; Engelmayr, G.C., Jr.; Melero-Martin, J.M.; Sacks, M.S. In vivo monitoring of function of autologous engineered pulmonary valve. J. Thorac. Cardiovasc. Surg. 2010, 139, 723-731. [CrossRef]

117. Dijkman, P.E.; Driessen-Mol, A.; de Heer, L.M.; Kluin, J.; van Herwerden, L.A.; Odermatt, B.; Baaijens, F.; Hoerstrup, S.P. Trans-apical versus surgical implantation of autologous ovine tissue-engineered heart valves. J. Heart Valve Dis. 2012, 21, 670-678.

118. Beachy, S.H.; Wizemann, T.; Hackmann, M. Exploring Sources of Variability Related to the Clinical Translation of Regenerative Engineering Products: Proceedings of a Workshop; The National Academies Press: Washington, DC, USA, 2019.

119. Wissing, T.B.; Bonito, V.; Bouten, C.V.; Smits, A.I. Biomaterial-driven in situ cardiovascular tissue engineering-A multidisciplinary perspective. NPJ Regen. Med. 2017, 2, 18. [CrossRef] [PubMed] 